\title{
Domestic work, sexual abuse, and exploitation in Tanzania
}

\author{
James K. Matheka \\ Elizabeth Shayo \\ Annabel Erulkar \\ Population Council
}

Follow this and additional works at: https://knowledgecommons.popcouncil.org/departments_sbsr-pgy

Part of the Demography, Population, and Ecology Commons, Family, Life Course, and Society Commons, Gender and Sexuality Commons, and the International Public Health Commons How does access to this work benefit you? Let us know!

\section{Recommended Citation}

Matheka, James K., Elizabeth Shayo, and Annabel Erulkar. 2020. "Domestic work, sexual abuse, and exploitation in Tanzania," brief. New York: Population Council. 
Domestic work is a common work role that is often the only option for many of the poorest and most disadvantaged girls and women.

The International Labour Office (ILO) estimates that there are 67 million domestic workers, globally, including 17.2 million children below the age of 18 and 7 million below the age of 15 (ILO 2017a; ILO 2017b; Anti-Slavery International 2018). The vast majority of domestic workers are women and girls, though patterns vary across countries (Anti-Slavery International 2018). The number of domestic workers in Tanzania is estimated to be over one million $(883,779$ in mainland Tanzania and 203,622 in Zanzibar), constituting 5 percent of the working population (ILO 2014).

Domestic work is characterized by excessive working hours, extremely low pay or no pay at all, and conditions that make the profession exploitive in many cases. Among children, domestic work keeps them out of school and deprived of a childhood, confined to the home, socially isolated, and burdened with excessive domestic duties, often in excess of their capabilities for their age (Black 2002). Younger domestic workers are often preferred by employers because they are thought to be easier to control and manipulate, demand little or no pay, and lack awareness of their rights (HRW 2006).

The abusive conditions of domestic work are compounded by the fact that the work is in the informal sector, with recruitment often occurring through informal kinship or broker networks. Domestic work is frequently unregulated by local labour laws, or there is ambiguity on the issue in legal codes. To address the abusive conditions of domestic work, ILO Convention 189, "The Domestic Workers Convention," was brought into force in 2013. It calls for normal hours of work for domestic workers, including weekly rest of at least 24 hours and paid annual leave; payment of minimum wage where one exists; enforcement of the minimum working age; a healthy and safe work environment and protection from all forms of abuse, harassment, violence, and more. Only 23 countries have ratified ILO's Convention 189; Tanzania has not yet ratified the Convention.

Evidence is emerging that domestic work is a feeder profession for sex work. One study of more than 2,000 commercial sex workers in Ethiopia found that 42 percent were former domestic workers (Girma and Erulkar 2009). However, little is known about transitions to commercial sex work (among young women aged 18 and over) or commercial sexual exploitation (among minors under age 18) in Tanzania.

The objective of the research was to expand the understanding of child domestic workers and commercial sex workers/girls who are commercially sexually exploited. It is anticipated that the results of this research will bring greater programmatic attention to the rights and protection of domestic workers and commercial sex workers, enforcement of minimum basic standards related to domestic work and improved, context-appropriate programs to help girls and young women transition into safer and more productive forms of work.

\section{METHODOLOGY}

This study was a collaboration between National Institute for Medical Research (NIMR) Dar es Salaam and the Population Council. The first phase was a qualitative study including in-depth interviews with domestic workers and commercial sex workers. The second

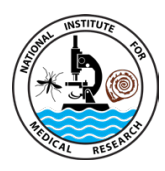

OAK FOUNDATION
NoVo Foundation create. change.
POPULATION COUNCIL

Ideas. Evidence. Impact. 
phase was a quantitative survey among the same populations. The study took place in two districts, each, of Dar es Salaam (Kinondoni and Temeke) and Mwanza (Nyamagana and Ilemela), two of the largest cities in Tanzania.

To select domestic workers for the quantitative study, a census of households within the study sites was conducted in which all household members were listed along with basic demographic information. Households with domestic workers aged 15 to 24, were considered eligible and were selected using a random number generator available in SPSS. Commercial sex workers (CSWs) are a hidden and stigmatized population. We identified neighborhoods where CSWs were known to reside, mainly in the low-income areas of the study districts. We used both household listings and snowball sampling to identify respondents for interview. Once identified, interviewers screened respondents for eligibility and undertook informed consent procedures, before conducting the interview. Twenty-seven female interviewers and a supervisor, all with prior interviewing experience, were recruited in both study sites. All interviewers were residents of Dar es Salaam or Mwanza. Therefore, they understood the local Kiswahili spoken in the study sites and were familiar with the local environment and conditions. Training was conducted by NIMR and Population Council staff. Ethical approval was obtained from the Population Council's Institutional Review Board and the Ethical Review Board at NIMR.

\section{RESULTS}

\section{Sample characteristics}

In total, 75 respondents were interviewed in-depth in the qualitative phase of the study: 52 domestic workers and 23 commercial sex workers. In the quantitative study, 1,415 girls and young women were interviewed, including 813 domestic workers and 602 commercial sex workers (Table 1).

Compared to domestic workers, commercial sex workers were significantly more likely to be orphaned and/or divorced. Twenty-two percent of commercial sex workers were double orphans compared to 8 percent of domestic workers. Fully 27 percent of commercial sex workers were formerly married, mainly divorced or separated, compared to only 3 percent of domestic workers.

\section{Education}

On average, girls in the study had less than 6 years of schooling. These low levels of schooling resulted in limited literacy. When asked if they could read a letter or newspaper, 63 percent reported that they could read easily, 20 percent of girls said that they read with difficulty and 17 percent said that could not read at all. There were no significant differences between domestic workers and commercial sex workers.

Respondents who ever attended school were asked the main reason they are no longer in school (Table 2). Reasons for drop-out did not differ significantly between domestic workers and sex workers. The most common reason cited for not being in school was that the family could not afford schooling (42 percent), followed by poor performance at school (39 percent) and completing a cycle of schooling and not progressing to the next level (22 percent). Notably, pregnancy was a reason for school-leaving among only 4 percent of girls; having no interest in schooling was a more common reason for leaving, among 5 percent of girls.

While the majority of respondents cited poverty and lack of school fees for the reason for leaving school, the in-depth interviews revealed situations that were far more complex. These included school administrations who were not sympathetic to the inability to pay, family disruptions and family members who were not supportive of schooling, and respondents feeling out of place at school due to late entry.

I was being beaten in school every day when I didn't pay school fees, so I decided to quit school. I didn't have school fees and, also, there were many other fees we were supposed to pay for... If you tell them I will bring [the money] tomorrow, you are told not to come to school. (Domestic worker, age 17, 9 years education)

I started school when I was older, and I was unable to read. I saw my classmates were younger and I was the oldest-I even had breasts-and I can't even read. My breasts were big. I was the oldest in that class, so I refused to go to school. All my ten siblings have gone up to class seven, except for me. (Commercial sex worker, age 20, 2 years education) 
TABLE 1. SAMPLE CHARACTERISTICS, BY CATEGORY OF RESPONDENT

\begin{tabular}{|c|c|c|c|}
\hline & $\begin{array}{c}\text { Domestic } \\
\text { workers } \\
(n=813)\end{array}$ & $\begin{array}{l}\text { Commercial sex } \\
\text { workers }(n=602)\end{array}$ & $\begin{array}{l}\text { All respondents } \\
\quad(n=1,415)\end{array}$ \\
\hline Age (mean)* & 18.2 & 21.1 & 19.5 \\
\hline \multicolumn{4}{|l|}{ Religion* } \\
\hline Catholic & 34.1 & 34.2 & 34.1 \\
\hline Muslim & 28.3 & 38.3 & 32.6 \\
\hline Protestant & 35.8 & 25.0 & 31.2 \\
\hline Other ${ }^{1}$ & 1.8 & 2.5 & 2.1 \\
\hline \multicolumn{4}{|l|}{ Educational attainment } \\
\hline None & 23.2 & 25.0 & 24.0 \\
\hline $1-4$ years & 4.4 & 4.4 & 4.4 \\
\hline $5-7$ years & 59.9 & 51.0 & 56.1 \\
\hline $8+$ years & 12.5 & 19.6 & 15.5 \\
\hline \multicolumn{4}{|l|}{ Number of living parents* } \\
\hline None & 7.7 & 21.7 & 13.6 \\
\hline One parent & 24.2 & 28.2 & 25.9 \\
\hline Two parents & 68.1 & 50.1 & 60.5 \\
\hline \multicolumn{4}{|l|}{ Marital status* } \\
\hline Never married & 96.5 & 70.6 & 85.6 \\
\hline Currently married & 0.3 & 2.6 & 1.2 \\
\hline Separated or divorced & 3.1 & 23.7 & 11.8 \\
\hline Widowed & 0.1 & 3.1 & 1.4 \\
\hline \multicolumn{4}{|l|}{ Study site } \\
\hline Dar es Salaam & 50.6 & 49.5 & 50.1 \\
\hline Mwanza & 49.4 & 50.5 & 49.9 \\
\hline
\end{tabular}

Note: Differences between groups significant at: * $p<0.001 ;{ }^{1}$ Other includes no religion and traditional religion.

TABLE 2. REASONS FOR DROPPING OUT OF SCHOOL $(n=1,075)$

\begin{tabular}{|l|c|}
\hline Reason & Percentage $^{1}$ \\
\hline Family could not afford schooling & 42.1 \\
\hline Poor performance at school & 39.3 \\
\hline Completed schooling cycle (primary or secondary) & 21.7 \\
\hline Death or separation of parents & 9.5 \\
\hline No interest in school & 5.4 \\
\hline Respondent got pregnant & 3.8 \\
\hline Respondent got married & 2.8 \\
\hline Parents did not approve/see the benefit & 2.2 \\
\hline Respondent had too many domestic duties & 1.4 \\
\hline
\end{tabular}

Note: Percentages may sum to over 100 percent as more than one response was allowed. 
When asked about vocational training, only 8 percent of girls had attended vocational training. When asked if they had put the vocational training to use in productive livelihoods, 51 percent said they had not, 41 percent said that they had, and the remainder reported they were still in training. When girls who had not put their skills to use were asked the reason, the most common response was lack of start-up capital.

\section{Social networks and community support}

When asked about their good female friends, a significant proportion of domestic workers (51 percent) reported having no friends whatsoever, compared to 21 percent of commercial sex workers. This is consistent with other studies of domestic workers, reporting few or no friends (Erulkar and Mekbib 2007, Erulkar and Ferede 2009). On average, commercial sex workers reported significantly more friends (mean 2.6), compared to domestic workers (mean 1.1) $(p<0.001)$.

Extremely limited social networks and support was also reflected in reporting of sources of support in the community. Respondents were asked a series of

\section{When asked about their good female friends, 51 percent of domestic workers reported having no friends whatsoever.}

agree-disagree statements related to their experience of support and safety in their neighborhoods (Table 3). Compared to domestic workers, commercial sex workers reported higher levels of support in their communities. They were more likely than domestic workers to report having someone to borrow money from (64 vs.

38 percent; $p<0.001)$, having an alternative place to stay (68 vs. 40 percent; $p<0.001$ ) and assistance in the case of a medical emergency (81 vs. 70 percent; $p<0.001$ ). Likewise, commercial sex workers had greater awareness and/or access to both HIV services (89 vs. 41 percent; $p<0.001$ ) and family planning services (FP) (88 vs. 37 percent; $p<0.001)$. While both groups expressed high levels of fear of being raped in their neighborhoods (73 percent), commercial sex workers felt significantly less protected by law enforcement compared to domestic workers (53 vs. 62 percent; $p<0.01$ ).

TABLE 3. COMMUNITY SUPPORT, SAFETY, AND ACCESS TO SERVICES, BY CATEGORY OF RESPONDENT

\begin{tabular}{|c|c|c|}
\hline Agrees with the statement & $\begin{array}{l}\text { Domestic workers } \\
\qquad(n=813)\end{array}$ & $\begin{array}{c}\text { Commercial sex } \\
\text { workers } \\
(n=602)\end{array}$ \\
\hline \multicolumn{3}{|l|}{ Community support and resources } \\
\hline $\begin{array}{l}\text { There is someone in your community from whom you can borrow money in an } \\
\text { emergency }\end{array}$ & 38.3 & $64.4 * * *$ \\
\hline $\begin{array}{l}\text { There is someone in your community with whom you could stay if you had a } \\
\text { problem }\end{array}$ & 40.1 & $68.2 * * *$ \\
\hline There is someone in your community you could confide in if you were raped & 54.5 & $72.2 * * *$ \\
\hline $\begin{array}{l}\text { There is someone in your community who would assist you in case of a medical } \\
\text { emergency }\end{array}$ & 69.5 & $80.5 * * *$ \\
\hline \multicolumn{3}{|l|}{ Community safety and protection } \\
\hline You fear being raped by someone in your neighborhood & 72.5 & 74.7 \\
\hline You feel protected by the police in your neighborhood & $62.2 * *$ & 53.4 \\
\hline \multicolumn{3}{|l|}{ Access to services } \\
\hline There is a place in your neighborhood you could go if you wanted HIV services & 40.9 & $89.2 * * *$ \\
\hline $\begin{array}{l}\text { There is a place in your neighborhood you could go if you wanted family planning } \\
\text { services }\end{array}$ & 36.7 & $88.4 * * *$ \\
\hline
\end{tabular}

Note: Differences between groups significant at: $* * p<0.01 * * * p<0.001$. 
Overall, a higher proportion of commercial sex workers reported being able to get HIV services (89 percent) and FP services ( 88 percent), compared to 41 and 37 percent of domestic workers respectively, a difference that was statistically significant.

\section{Migration}

Eighty-four percent of respondents were not native to the area but had migrated from another location, with no significant difference between the two categories of respondents. When asked about their place of origin, most migrants (71 percent) came from rural areas, while 20 percent came from small towns and 9 percent came from other big cities. On average, migrant girls first moved at the age of 15.9, with those in Mwanza first moving at significantly younger ages (15.4 years), compared to those in Dar es Salaam (16.4 years). The reason for moving was overwhelmingly for work (76 percent); 7 percent moved to escape problems at home and 4 percent moved for schooling.

I left home because, after my father left us, the situation in our home got worse. We didn't have anything. We were being helped by neighbors. I was happy when my younger siblings were taken away and I came here to do domestic work...She

\section{Some respondents were encouraged to migrate through deception, an indication of trafficking: 1 in 5 girls was deceived or tricked into moving.}

[employer] sent me money for bus fare and told me to alight at Busuruga and someone will pick me up. When I alighted, I found someone who picked me up. (Domestic worker, age 15, 7 years education)

Commercial sex workers in the study tended to report more assistance and support for migration, especially by non-family members (Table 4). They were significantly more likely than domestic workers to report being encouraged by a neighbor or friend to migrate (47 vs. 15 percent; $p<0.001$ ), and more likely to know of a person in their hometown who would help them migrate (45 vs. 23 percent; $p<0.001$ ). Commercial sex workers were also more likely to know of brokers who would help them find a job, compared to domestic workers (15 vs. 5 percent; $p<0.001)$. In contrast, domestic workers were significantly more likely to have been encouraged to migrate by one or both of their parents, compared to commercial sex workers (18 vs. 8 percent; $p<0.001$ ).

\section{TABLE 4. ASSISTANCE DURING MIGRATION AND INDICATIONS OF TRAFFICKING, BY CATEGORY OF RESPONDENT}

\begin{tabular}{|c|c|c|}
\hline & $\begin{array}{l}\text { Domestic workers } \\
\qquad(n=791)\end{array}$ & $\begin{array}{c}\text { Commercial sex } \\
\text { workers } \\
(n=596)\end{array}$ \\
\hline You know a person in your hometown who would help you migrate & 22.9 & $45.2 * * *$ \\
\hline You have been encouraged to migrate by a neighbor or a friend & 15.4 & $47.0 * * *$ \\
\hline You have been encouraged to migrate by one or both of your parents & $17.7 * * *$ & 8.4 \\
\hline You know of a broker in another town who would help you find a job & 5.1 & $15.0 * * *$ \\
\hline Has been convinced to move because of lies/deception & 12.5 & $33.9 * * *$ \\
\hline \multicolumn{3}{|l|}{ Person who deceived respondent to move ${ }^{1}$} \\
\hline Family member & $19.8 * * *$ & 8.0 \\
\hline Neighbor & 47.3 & 23.4 \\
\hline Acquaintance & 31.9 & 65.4 \\
\hline Employer & 1.1 & 3.2 \\
\hline Person who misled tried to have sex or arrange sex with others ${ }^{1}$ & 4.3 & $18.0 * *$ \\
\hline
\end{tabular}

Note: ${ }^{1}$ Among those who have moved because of lies or deception; Differences between groups significant at: $* p<0.5 * * p<0.01 * * * p<0.001$ 
TABLE 5. GIRLS' FINANCIAL SUPPORT AND SAVINGS, BY CATEGORY OF RESPONDENT

\begin{tabular}{|c|c|c|c|}
\hline & $\begin{array}{l}\text { Domestic workers } \\
\qquad(\mathrm{n}=801)\end{array}$ & $\begin{array}{l}\text { Commercial sex } \\
\text { workers } \\
(n=602)\end{array}$ & $\begin{array}{c}\text { All } \\
(n=1,403)\end{array}$ \\
\hline \multicolumn{4}{|l|}{ Financial support } \\
\hline Receives financial support from others & 25.3 & 31.7 & 28.0 \\
\hline Provides financial support to others & 73.7 & 72.3 & 73.1 \\
\hline \multicolumn{4}{|l|}{ Provides financial support to ${ }^{1:}$} \\
\hline Mother & $82.9 * * *$ & 62.0 & 74.1 \\
\hline Father & $42.4 * * *$ & 24.1 & 34.6 \\
\hline Siblings & 19.9 & $27.9 * *$ & 23.3 \\
\hline Own children & 4.6 & $42.7 * * *$ & 20.8 \\
\hline \multicolumn{4}{|l|}{ Savings } \\
\hline Has savings & 59.4 & 55.4 & 57.7 \\
\hline Amount of savings (mean) & $\begin{array}{l}\text { TSH } 102,752 \\
\sim \text { USD } 45\end{array}$ & $\begin{array}{c}\text { TSH } 190,146 * * * \\
\sim \text { USD } 83\end{array}$ & $\begin{array}{l}\text { TSH } 138,451 \\
\sim \text { USD } 61\end{array}$ \\
\hline
\end{tabular}

Note: ${ }^{1}$ Among those providing any financial support to others; Differences between groups significant at: $* * p<0.01 * * * p<0.001$

Some respondents were encouraged to migrate through deception, which is an indication of trafficking. One in five girls was deceived or tricked into moving. This was significantly more common among commercial sex workers (34 percent) compared to domestic workers (13 percent). Among commercial sex workers, the majority of people who deceived girls were acquaintances (65 percent) and 18 percent of commercial sex workers reported that the trafficker attempted to have sex with them or arranged for them to have sex with others.

\section{Livelihoods}

The vast majority (73 percent) provided financial assistance to others (Table 5). Domestic workers were significantly more likely to support their mothers (83 percent of those providing support) compared to sex workers (62 percent of those providing support) $(p<0.001)$. Sex workers were significantly more likely to be supporting their own children (43 percent of those providing support) compared to domestic workers (5 percent of those providing support) $(p<0.001)$.

Just over half of the respondents (58 percent) had personal cash savings. However, among those having savings, commercial sex workers had considerably more than domestic workers (mean savings TSH 190,146 among sex workers and TSH 102,752 among domestic workers). That sex workers were able to save more money is perhaps a reflection of their income. Sex workers mean monthly income was nearly seven times that of domestic workers (mean income TSH 276,608 among sex workers and TSH 40,079 among domestic workers).

Figure 1 is based on work histories collected from respondents and shows the percent distribution of types of work respondents engaged in during their first and second paid job. It should be recalled that the survey sample consisted of only domestic workers and sex workers, making this distribution not representative of the population of girls and young women aged 15 to 24. Overwhelmingly, girls' first paid work was domestic work, reported by 74 percent of girls in the survey. Other first paid work reported included commercial sex work (19 percent), petty trade (3 percent) and service industry (4 percent). However, by the second paid work, a considerable number of girls transitioned out of domestic work and into sex work. By the second paid work, only 48 percent of girls were still in domestic work 


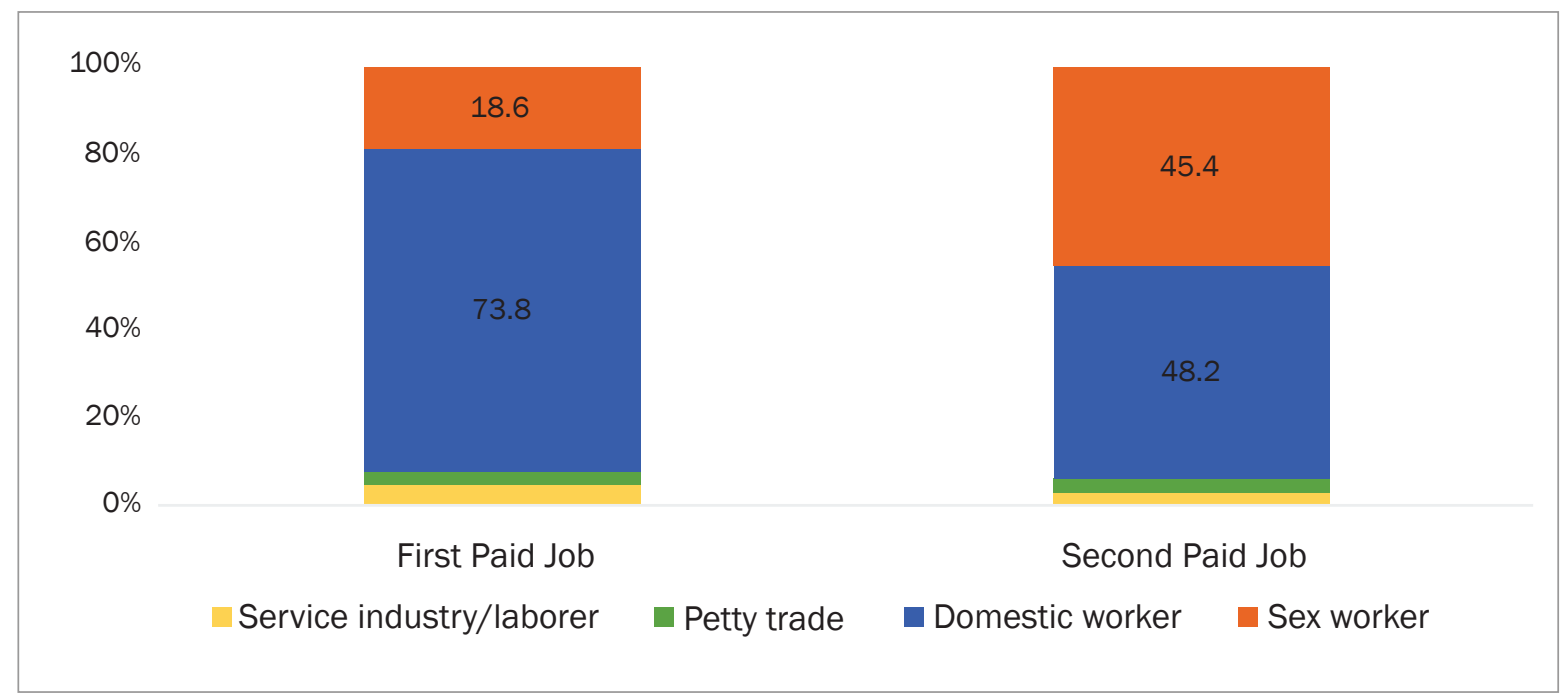

Among commercial sex workers, 58 percent had previously worked in domestic work. Forty percent reported that they entered commercial sex work to leave abusive work, such as domestic work.

compared to 45 percent of girls in sex work, 4 percent doing petty trade and 3 percent in the service industry. In fact, among girls whose second job was commercial sex work, 58 percent had previously worked in domestic work.

\section{Domestic work}

Nineteen percent of domestic workers started domestic work before they were 15 years old, while 89 percent reported that they started domestic work before they were 18 years old. Many girls reported very difficult conditions while working in domestic work, including excessive workloads, physical violence, and abusive employers.

When I woke up, first I cooked the boss's tea then the children's tea, and then tea for other ladies as well. Then I did laundry. I also cooked lunch. When they left the house, there were so many dishes to do and I was alone... I was overwhelmed... If I did some chore, she [employer] would come back and say I hadn't done it. Then she would beat me. Even when I would give her child food, she would say I hadn't done it. When I wanted to call my mother, she told me she had no phone credit, and she would say she would call my mother later and lie to me. (Domestic worker, age 15, 7 years education)

When you cook food, she tells you, you have cooked it badly. She tells you, you are not sweeping well because you have become used to life in the village. She was insulting me and my family. Other times she tells you, 'Thank God I am helping you; I am feeding you and giving you a place to sleep, and also paying you.' So, I kept on wondering is this how rich people behave? Where will poor people go? But, you know, those who mistreat the poor will be mistreated in heaven. (Commercial sex worker, age 24, 7 years education)

A number of girls described sexual abuse in the context of domestic work.

Her [the employer's] husband was not a faithful person. He would want to touch my breasts which were very firm since I am from the village. But he found that I was not interested in such things. On the day which he wanted to do something to me, he stood in my way in the corridor. (Commercial sex worker, age 24,7 years education) 


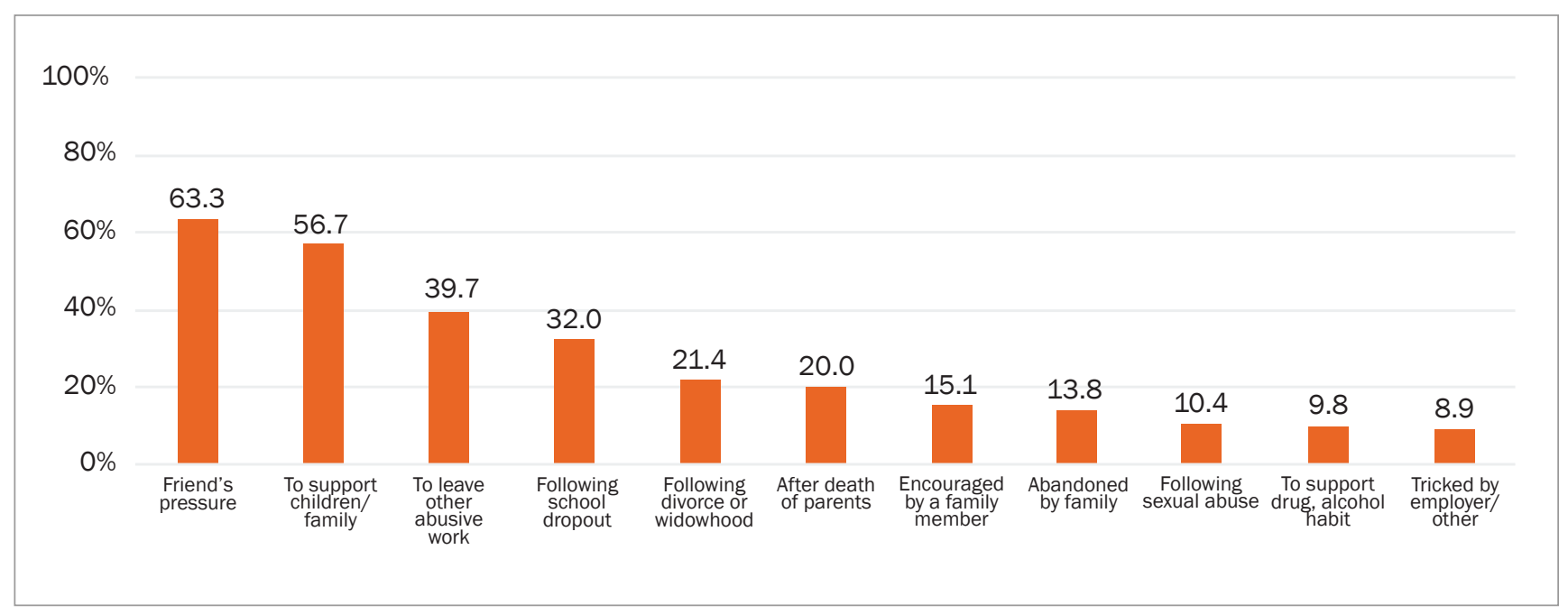

\section{Commercial sex work and commercial sexual exploitation}

Twenty-seven percent of respondents started sex work as minors, below the age of 18; 7 percent started below the age of 15, making all of these girls trafficked children and commercially sexually exploited. About 1 out of 5 girls (18 percent) experienced their sexual initiation within the context of commercial sexual exploitation.

Respondents engaged in commercial sex work/ commercial sexual exploitation were read a series of statements regarding their entry into commercial sex work and asked if they agreed or disagreed with the statement (Figure 2). Nearly two-thirds (63 percent) of young women in commercial sex work agreed with the statement that they started work after being pressured by female friends; over half (57 percent) said they started the work to support their own children or family members; 40 percent reported that they entered commercial sex work to leave other forms of abusive work, such as domestic work. Of note, 1 in 7 commercial sex workers (15 percent) reported that they entered commercial sex work with the encouragement of a family member. Among those encouraged by family members, 30 percent originated from Kagera, followed by Mwanza (19 percent). Nearly 1 in 10 (9 percent) entered sex work when they were tricked by an employer or another person, which constitutes trafficking.
Twenty-seven percent of commercial sex workers started the work below the age of 18; 7 percent started below the age of 15 .

Respondents in the survey described a significant amount of pressure from friends and economic circumstances as motivators for entry into sex work. However, the qualitative results provided a more nuanced picture of how girls transitioned to commercial sex work and commercial sexual exploitation. While pressure from friends and economic stresses were prominent factors in these transitions, exploitive conditions in domestic work and issues of accommodation, safety and security frequently played a role in these transitions.

I got another job as a domestic worker, but it was very challenging. My pay used to be delayed and there was harassment on the job... After a lot of domestic work, one friend asked me why I am working and not getting good money out of the job. She promised to introduce me to it [sex work]... I told her I was scared to do it, but she assured me that I will get used to it. (Commercial sex worker, age 18, 3 years education)

The lady who hired me as a domestic worker used to hate me. I had to go out and ask people for a place 
to sleep. Instead of giving me a place to sleep, they would tell me, 'Go and sleep with a man.' But you can't just sleep with a man in the same bed without him asking. He tells you, 'I can help you, but you also have to help me.' He sleeps with you and he doesn't pay you anything. So, you think about it. You have slept with a man and you still wake up hungry... (Commercial sex worker, age 24, 7 years education)

Many commercial sex workers described circumstances of trafficking, including being brought into the profession and being brought clients by others:

I came looking for a job. I alighted from the bus at this place, but I didn't know about the city. So, I went and asked some ladies for help. They brought me here trained me and they found clients for me to sleep with... (Commercial sex worker, age 24, 7 years education)

I left Kawe for Kinondoni on foot. I met some ladies who introduced me [to sex work]. I called one of the ladies and asked for a job and she told me to relax and that I had already found one. Then she told me go with her to Mwenge Street. When we reached there, there was a car that belonged to Arabs. She called one and told him 'you had asked for a young girl whose breasts are upright. Here she is.' Then I got in the car, but I had not started sleeping with men..I was about 12. (Commercial sex worker, age 24, 7 years education)

Commercial sex workers also described being conflicted about engaging in the work. They described it as going against their values but feeling that they had no choice.

I was thinking about it [becoming a sex worker] when I had many problems ... The first day I wasn't used to it. In my heart I didn't have peace. I wasn't happy because I felt like I am sinning against God and against the community. I am going against the values that I have been raised with, but I didn't have any other option because I had searched for a job for a very long time. (Commercial sex worker, age 24 , 7 years education)
Commercial sex workers also reported a considerable amount of violence in the context of their jobs, including gang rape:

I was raped by two men and then they left me. It was just when I had started doing this business, I was new to it. I was 15 years, near the ferry. They chased me with a machete and when they got to me, there undressed me and raped me two times. That is when others came and asked why they were doing that to me, and they asked them to stop and they stopped and let me go. (Commercial sex worker, age 20, 3 years education)

\section{CONCLUSIONS AND RECOMMENDATIONS}

The results from this study provide important information on domestic workers and commercial sex workers in two of Tanzania's largest cities: Dar es Salaam and Mwanza. The study found that young women in both groups come from extremely disadvantaged backgrounds. Both groups have low levels of education and one-quarter have never been to school. Among sex workers, a significant proportion are divorced and supporting children.

The majority of the respondents migrated from another location. Upon arriving in the city, many migrants enter domestic work as a survival strategy; among our sample, 74 percent reported their first paid work was domestic work. However, many ultimately drift into commercial sex work or commercial sexual exploitation. Entry into commercial sex work often results following abuse and exploitation in domestic work, including receiving little or no pay and being physically and sexually abused. Fiftyeight percent of sex workers in the sample are former domestic workers. A significant number of respondents described being trafficked into the profession through deception and force and a number of girls described gang rape. The study provides important direction for programs: 


\section{Expanding girls' work options- especially for the most marginalized and disadvantaged-should be priority.}

\section{Improve working conditions of domestic workers}

Domestic work absorbs a large number of girls entering the work world, especially girls from poor backgrounds, with low levels of education. Domestic workers typically experience long working hours, very low pay and, frequently, physical and sexual abuse. Increased awareness is needed regarding the rights of domestic workers, with additional attention given to the conditions of work, pay and treatment by employers. ILO's Convention 189, "The Domestic Workers Convention," was brought into force in 2013 , but few countries have ratified it. It calls for normal hours of work, weekly rest, payment of minimum wage, enforcement of the minimum working age, and protection from abuse, harassment and violence. Consideration of Convention 189 is warranted along with development of national and community-level mechanisms to support and protect domestic workers.

\section{Increased attention to trafficking, especially into commercial sex work}

A significant number of girls and young women described entry into sex work under circumstances of deception, coercion, or force. Many migrants were driven into sex work shortly after migration, often lacking familiarity with their destination towns and with no other means of supporting themselves. Few programs attempt to prevent trafficking of girls and young women into commercial sex work, in particular domestic trafficking. Action needs to be taken against perpetrators who traffic girls into commercial sex work/commercial sexual exploitation. In addition, programs need to equip girls with the awareness and understanding of the risks of trafficking and sex work, as well as tools to plan and manage safer migration.

\section{Skills and support to enter safer livelihoods for girls and young women}

This study highlights the hazardous conditions of some of the most common forms of work occupied by girls and young women. The dangerous and exploitive nature of both domestic work and commercial sex work is compounded by the fact that girls who enter these professions are typically marginalized and disadvantaged; they come from poor backgrounds, with low levels of education and limited familiarity and support systems in the urban environment. Expanding girls' work options-especially for the most marginalized and disadvantaged-should be priority. Programs should provide girls with knowledge and skills to enter safer forms of work. Skills needed to transition to safer, more productive work may include basic literacy and numeracy, financial literacy, entrepreneurship skills and mentoring by women in small businesses and other professions.

\section{Increased protection of and support for girls and women who are victims of violence}

Girls and young women described a substantial amount of violence, both physical and sexual. Respondents -especially commercial sex workers-experienced beatings and gang rape. Additional infrastructure and services are needed to support the large proportion of women who are victims of violence. The stigma related to experiencing violence needs to be addressed through public awareness campaigns, and social and support services need to improve the quality of response to all forms of violence. 


\section{REFERENCES}

Anti-Slavery International. 2018. Domestic work and slavery, https://www.antislavery.org/slavery-today/domestic-work-andslavery/ accessed January 29, 2018.

Black, M. 2002. "Child Domestic Workers: Finding a Voice." London: Anti-Slavery International.

Erulkar A. and A. Ferede. 2009. "Social exclusion and early, unwanted sexual initiation in poor urban settings in Ethiopia," International Perspectives on Sexual and Reproductive Health 35(4): 186-193.

Erulkar A. and T. Mekbib. 2007. "Invisible and vulnerable: Adolescent domestic workers in Addis Ababa, Ethiopia," Vulnerable Child and Youth Studies 2(3): 246-256.

Girma W. and A. Erulkar. 2009. "Commercial sex workers in five Ethiopian cities: A baseline survey for targeted HIV prevention for most-at-risk populations." Report. Addis Ababa: Population Council.

Human Rights Watch (HRW). 2006. "Swept under the rug: Abuses against domestic workers around the world," Human Rights Watch 18(7).

ILO. 2014. "Domestic Workers in the United Republic of Tanzania: Summary of Findings of a Situational Analysis 2013." Dar es Salaam: ILO Country Office.

ILO. 2016. "A Situational Analysis of Domestic Workers in the United Republic of Tanzania." Dar es Salaam: ILO Country Office.

ILO. 2017a. "Formalizing Domestic Work," Domestic Work Policy Brief No. 10. Geneva: ILO.

ILO. 2017b. Child labour and domestic work, https://www.ilo.org/ ipec/areas/Childdomesticlabour/lang--en/index.htm, accessed May 1, 2020.

\section{ACKNOWLEDGMENTS}

This study would not have been possible without the financial and technical support of the Oak Foundation and the NoVo Foundation. We acknowledge the assistance and support of the Ministry of Health, Community Development, Gender, Elderly and Children (MoHCDGEC), National AIDS Control Program (NACP), International Labour Organization (ILO), International Organization for Migration (IOM), and local NGOs working with commercial sex workers and domestic workers in Dar es Salaam and Mwanza. We sincerely thank Ben Ochieng for coordinating the first phase of the study. Mtumwa Bakari, Doris Mbata, Rogers Msangi, Susan Rumisha, Roseline Michael and Florian Lugariki provided supervision that made the survey possible. We appreciate numerous interviewers who participated in data collection. We are indebted to the staff of National Institute of Medical Research (NIMR) in Dar es Salaam and Mwanza for their assistance during data collection. We thank Corinne White for comments on this paper and Joyce Altman for editing support. Finally, we thank the respondents who participated in the study and were so giving of their time and experience and from whom we have learned a lot.

Suggested citation: Matheka, James, Elizabeth Shayo, and Annabel Erulkar. 2020. "Domestic work, sexual abuse, and exploitation in Tanzania," brief. New York: Population Council.

(C) 2020 The Population Council, Inc.
NoVo Foundation create. change.
POPULATION COUNCIL

Ideas. Evidence. Impact. 